\title{
Reactions in leprosy
}

\author{
G BJUNE \\ Ullevaal Hospital, Laboratory for Microbiology, Oslo 1, Norway
}

\section{Introduction}

Without leprosy reactions, this feared disease would have constituted little more than a cosmetic problem. Mycobacterium leprae is close to being 'the perfect parasite'. Lepromatous patients can harbour up to $10^{13}$ bacilli in their body without overt symptoms or discomfort. On the other side, a tuberculoid leprosy patient can be seriously crippled containing a number of bacilli which is below the present detection level. The reason for this great discrepancy between degree of infection and degree of disease is the variability of the immune response to the invader, justifying leprosy being named an 'immunological disease'. During the course of the disease, roughly $25 \%$ of all leprosy patients develop such serious immune reactions that they become chronically disabled. This, the public (including patients), know. They also know that the present antileprosy treatment offers little protection to leprosy reactions, and many thus have no urge to register for therapy. A better understanding and handling of reactions would probably result in a major reduction in the world's non-registered leprosy patients, presently estimated to be more than $50 \%$ of all cases - and thus to better leprosy control. Not to mention the tremendous amount of human suffering caused by these reactions. This is perhaps best illustrated by the observation that suicide was the commonest cause of death in some leprosaria prior to the introduction of efficient pain control by erythema nodosum leprosum.

\section{History}

Fairly precise clinical descriptions of leprosy reactions were recorded from $1895,{ }^{1}$ and reached some degree of classification in Cochrane's classical textbook, $1959 .{ }^{2}$ A more pathogenic, and still valid classification, was reached by fundamental histopathological studies, $1969 .{ }^{3}$ Reactions in borderline leprosy, type I leprosy reactions or reversal reaction, were characterized by a heavy mononuclear 
infiltration and destruction of dermal nerves. Reactions in lepromatous leprosy, type II leprosy reactions or erythema nodosum leprosum (ENL), were dominated by an acute inflammatory exudate with mainly polymorphonucleated granulocytes centred around heavily infected macrophages. In this classification 'Lucio reaction' with an intensive necrotizing vasculitis on an ENL-suggestive background, and 'downgrading reactions' causing a shift in the clinical picture towards the lepromatous pole, were not given a definitive place. Lucio reactions have later on defended a specific position as a variant of ENL, while downgrading reactions at present have only a historic interest, as 'downgrading' will not occur in patients on efficient antileprosy treatment.

\section{Type I leprosy reactions}

The pioneer work in elucidating the mechanism of type I leprosy reactions was done by Rees \& Weddell. ${ }^{4}$ In Mycobacterium leprae infected mice deprived of cell-mediated immune responses by thymectomy and whole body irradiation, and then bone-marrow reconstituted, they could provoke a type I-like reaction by injection of $\mathrm{T}$ lymphocytes. The reaction occurred about 10 days after $\mathrm{T}$-cell reconstitution, and the inflammatory infiltrate was predominated by small lymphocytes and activated macrophages. This timing fits well with the peak of the 'tuberculin-type' of delayed-type hypersensitivity (DTH) in intact mice infected with mycobacteria. ${ }^{5}$ Godal et al. ${ }^{6}$ found higher in vitro lymphocyte responses to $M$. leprae antigens in reactions compared to non-reactional borderline leprosy patients. Longitudinal studies, ${ }^{7,8}$ showed that there was a temporary increase in these responses during type I reactions and that the in vitro lymphocyte responses to $M$. leprae antigens correlated well with clinical and histological evidence of $\mathrm{DTH}$ in the lesions. The in vitro lymphocyte stimulation test gave on average higher responses in reactional $\mathrm{BL}$ patients than in non-reactional BT patients, and was virtually negative in BT patients with an indeterminate histology. The latter patients, however, control bacillary growth fairly well, and the picture thus became similar to tuberculosis where immune protection and DTH expressed as tuberculin reactivity can be clearly separated experimentally. ${ }^{9}$ This does not mean that DTH to $M$. leprae only causes immune complications in leprosy. Probably the positive function of this immune mechanism in leprosy is containment and prevention of spread of the infection-similar to Koch's phenomenon in tuberculosis-rather than a sterilizing effect which is neccessary for immune resistance.

For a long time it was speculated that antileprosy treatment with dapsone caused a sudden release of mycobacterial antigens which could trigger reactions. It was thus recommended that dapsone treatment should start with a small dose and build up slowly. The likelihood for a bacteriostatic drug causing a sudden release of bacillary antigen is theoretically small, and the bactericidal drug, 
rifampicin, has not caused the expected increase in reactions. Barnetson ${ }^{10}$ compared BT patients started on $5 \mathrm{mg}$ and $50 \mathrm{mg}$ of dapsone daily, and found no evidence of increased reactions in the latter group. Neither were concomitant infections or immunizations found to precipitate reactions.

On the other hand, nerve reactions have a tendency to start in segments of the nerves that are easily traumatized. In this situation a shift of bacilli to cells that better expose their antigens to immunocompetent lymphocytes is possible. Ordinarily leprosy bacilli have two host cells in the human body, skin macrophages and Schwann cells of myelinated nerves. For lymphocytes to respond with a DTH reaction, the antigen has to be exposed on a cell surface together with histocompatibility antigens of the HLA-D series. These histocompatibility antigens are known to be present on skin macrophages (and some other cells which can be infected, like Langhans' cells in epidermis), but are possibly lacking from the surface of Schwann cells. This might explain why BT patients can have large numbers of bacilli in some nerves without any neuritis and at the same time the skin can be severely inflamed with only a few bacilli detectable. A traumatic release of bacilli from Schwann cells will bring them into infiltrating macrophages and stimulate a DTH neuritis. Why this happens in only a quarter of the leprosy patients seems to have a genetic basis. DeVries ${ }^{11}$ showed that patients in the tuberculoid part of the leprosy spectrum had an HLA-linked susceptibility to develop this specific type of leprosy. They later showed that this tendency was associated to the HLA-DR-3 antigen, an antigen which is associated to vigorous DTH reactions to other antigens as well.

Type I reactions seem to occur earlier in the treatment phase of BT than of BL patients who have more immunosuppressive factors in their plasma. ${ }^{12,13}$ They are rare during pregnancy when cell-mediated immunity is suppressed, but increase drastically in the puerperium when this suppression wanes. ${ }^{14}$ The reactions are also efficiently controlled by immunosuppressive drugs such as corticosteroids. ${ }^{15}$ These observations indicate that type I reactions are susceptible to a dynamic immune regulation in the patients. During reactions, BT patients' plasma change from suppression of global T-lymphocyte responses to an augmentation of these responses compatible to a loss of 'immunological brakes'. This augmentation by reactional plasma came, however, later than clinical signs of reaction in $\mathrm{BL}$ patients. Either the augmenting factor(s) were absorbed out at the receptor site early in BL reactions, or the phenomenon is secondary rather than primary to the reactions. ${ }^{13}$ Stress and inflammation-induced humoral factors like corticosteroids and prostaglandins would expectantly have the opposite effect on the immune response. Specific antibody levels were not raised during reactions although general immunoglobulin levels increased. ${ }^{16}$ The nature of the plasma factor(s) 'normally' controlling type I reactions is still unknown, but should be studied as they might offer interesting therapeutic possibilities.

The immune response is also under strict control of immunoregulatory cells. In murine leprosy, ${ }^{17,} 18$ in fungal infections ${ }^{19}$ and in schistosomiasis, ${ }^{20}$ suppressor $\mathrm{T}$ 
cells are involved. Suppressor cells in leprosy were first suggested as a pathogenic factor in lepromatous leprosy ${ }^{21}$ and evidence for such suppression has been published, ${ }^{22,23}$ but Nath et al. ${ }^{24}$ using a different suppressor cell assay, found evidence for a decreased suppressor activity in lepromatous leprosy. As T-cell suppression can be both general and antigen specific, and different assay systems will reflect this differently, these results might not be contradictory. T lymphocytes can suppress specific DTH in mice, ${ }^{25}$ and a similar suppression of $M$. leprae-induced DTH might be an important mechanism in borderline leprosy, failing its purpose in those who develop inflamed lesions and reactions. Interestingly, impaired suppressor function in myastenia gravis is linked to HLA-DR 3 and cold-reactive lymphotoxic antibodies; ${ }^{26}$ both recorded increases in tuberculoid leprosy patients. ${ }^{27,}{ }^{28}$ HLA-D typing and testing for cold-reactive lymphotoxic antibodies might thus be a method to identify borderline leprosy at risk to develop reactions, but data to substantiate this hypothesis are lacking.

The nature of the antigen(s) involved in DTH to $M$. leprae is also incompletely known. Closs et al. ${ }^{29}$ has purified a cell wall component (M. leprae cell wall ag. 1) which is a powerful antigenic stimulus for sensitized lymphocytes in vitro. A cross-reacting cell wall component from $M$. tuberculosis is the principal stimulating antigen in tuberculin. This antigen is present both on whole bacilli and in sonicates of $M$. leprae, and will probably lodge in the tissues long after bacilli are dead. Other antigens might be involved, ${ }^{7}$ as suggested by a predominance of the response to whole bacilli in skin reactions and to sonicated bacilli in nerve reactions. This does not, however, exclude that the same antigenic determinant could be involved in both, only differently exposed in skin (mainly cell wall remnants of dead bacilli) and nerves (mainly live bacilli). The re-establishment of a positive lepromin reaction by injection of dead $M$. leprae and $\mathrm{BCG},{ }^{30}$ followed by skin inflammation but no neuritis, could similarly be explained by a difference in skin and nerve presentation of antigen. This creates hope that cell-mediated immunity could be re-established in lepromatous leprosy without necessarily provoking neuritis.

\section{Erythema nodosum leprosum}

In erythema nodosum leprosum (ENL), granular deposits of immunoglobulin and complement were found to correspond to areas of clinical lesions with polymorphonuclear infiltration. ${ }^{31}$ This suggested an immune complex genesis of the lesions which could be caused either by local release of antigen (Arthus phenomenon) or systemic release with circulating immune complexes ('serum sickness'). Other symptoms compatible with serum sickness-fever, albuminuria, arthritis, etc. - can occur in ENL, but are relatively rare complications. This, together with the finding of raised levels of C3d only in ENL patients ${ }^{32}$ and the presence of circulating immune complexes also in non-ENL lepromatous 
patients, suggested the importance of locally, extravascularly formed immune complexes. Activation of $\mathrm{C} 3$ by antibodies could explain all the observed pathology expressed in ENL. In cases of inadequate antibody responses immune complexes would be formed in antigen excess. Such complexes would circulate for a prolonged time and cause chronic kidney disease, ${ }^{33}$ but this complication does not correlate with the occurrence of ENL. ${ }^{34} \mathrm{ENL}$ is often precipitated by intercurrent diseases like tuberculosis (or BCG vaccination), which could cause antigen release by immune reactions to cross-reacting antigens, and viral diseases (or live virus vaccines), which could cause release of mycobacterial antigens from cells concomitantly infected with virus.

Chronic and recurrent ENL is a very distressing complication in leprosy, and the only type of ENL which can cause chronic disability. This should logically be treated with plasma exchange in combination with a B-cell cytotoxic drug like metotrexate. As yet no study has been published which could show the efficiency of such an approach.

\section{Lucio's phenomenon}

The study of Rea \& Ridley ${ }^{35}$ has given strong support to the view that Lucio's phenomenon is a variant of ENL. The reason for its special clinical picture seems to be the presence of Mycobacterium leprae in endothelial cells. Antigen release from this location can cause an intensive vasculitis with thrombotic occlusion of vessels due to activation of coagulation by C6. The ethnic peculiarity of Mexican patients versus leprosy patients in other parts of the world is thrilling. They show more diffuse lepromatous leprosy with less neurotropism and more endothelial tropism of the infection, as well as a high incidence of Lucio reactions. This might indicate the existence of specific cell receptors for the penetrance of $M$. leprae determinant for the specific localization of the infection to certain host cells and possibly to a certain fraction of the population.

\section{References}

${ }^{1}$ Hansen GA, Looft C. Leprosy: in Its Clinical and Pathological Aspects. Bristol: John Wright, 1895.

2 Cochrane R.G. Leprosy in Theory and Practice. Bristol: John Wright, 1959.

${ }^{3}$ Ridley DS. Reactions in leprosy. Lepr Rev, 1969; 40: 77.

${ }^{4}$ Rees RJ, Weddell AG. An experimental model in mice for studying the reversal reaction. Int $J$ Lepr, 1968; 36: 629.

5 Rook GAW. Three forms of delayed skin-test response evoked by mycobacteria. Nature (Lond.), 1978; 271: 64.

${ }^{6}$ Godal T, Myrvang B, Samuel DR, Ross WF, Löf gren M. Mechanism of 'reactions' in borderline tuberculoid (BT) leprosy. Acta Pathol Microbiol Scand, 1973; (Sect. A. Suppl), 236: 45. 
7 Barnetson R St C, Bjune G, Pearson JMH, Kronvall G. Antigenic heterogeneity of patients with reactions in borderline leprosy. $\mathrm{Br}$ Med $J$, 1975; 4: 435.

${ }^{8}$ Bjune G, Barnetson R St C, Ridley DS, Kronvall G. Lymphocyte transformation test in leprosy: correlation of the response with inflammation of lesions. Clin exp Immunol, 1976; 25, 85.

9 Youmans GP. Relation between delayed hypersensitivity and protective immunity in tuberculosis. Am Rev resp Dis, 1975; 111: 109.

${ }^{10}$ Barnetson R St C, Pearson JMH, Rees RJW. Evidence for prevention of borderline leprosy reactions by dapsone. Lancet, 1976; 2: 1171.

11 DeVries RRP, Lai A Fat RFM, Nijenhuis LE, van Rood JJ. HLA-linked control of host response to Mycobacterium leprae. Lancet, 1976; 2: 1328.

12 Naafs B, Wheate HW. The time interval between the start of anti-leprosy treatment and the development of reactions in borderline patients. Lepr Rev, 1978; 49: 153.

13 Bjune G, Barnetson R St C. Plasma factors in delayed-type hypersensitivity. Augmentation of lymphocyte responses in borderline leprosy reactions. Clin exp Immunol, 1976; 26: 397.

${ }^{14}$ Duncan ME, Melsom R, Pearson JMH, Ridley DS. The association of pregnancy and leprosy. I. New cases, relapse of cured patients and deterioration in patients on treatment during pregnancy and lactation. Results of a prospective study of 154 pregnancies in 147 Ethiopian women. Lepr Rev, 1981; 52: 245.

15 Waters MFR. Treatment of reactions in leprosy. Lepr Rev, 1974; 45: 337.

16 Barnetson R St C, Barnetson A, Pearson JMH, Kronvall G. Does non-specific T-lymphocyte stimulation of B lymphocytes occur during reversal reaction in borderline leprosy? Scand $J$ Immunol, 1976; 5: 287.

17 Bullock W, Carlson E. Evolution of suppressor cell populations in experimental mycobacterial infection. Fed Proc, 1977; 36: 1271.

18 Turcotte R. Suppressor cells in experimental murine leprosy. Int J Lepr, 1978; 46: 358.

19 Stobo JD, Paul S, van Scoy RE, Hermans PE. Suppressor thymus-derived lymphocytes in fungal infection. J Clin Invest, 1976; 57: 319.

${ }^{20}$ Pelley RP, Ruffier JJ, Warren KS. Suppressive effect of a chronic helmintic infection, schistosomiasis mansoni, on the in vitro responses of spleen and lymph node cells to the T-cell mitogens phytohaemagglutinin and concanavalin A. Infect Immunity, 1976; 13: 1176.

21 Turk JL. Leprosy as a model of subacute and chronic immunological diseases. J Invest Dermatol, 1976; 67: 457.

22 Mehra V, Mason LH, Fields JP, Bloom BR. Lepromin-induced suppressor cells in patients with leprosy. J Immunol, 1979; 123: 1813.

${ }^{23}$ Bjune G. In vitro lymphocyte stimulation in leprosy: Simultaneous stimulation with Mycobacterium leprae antigens and phytohaemagglutinin. Clin exp Immunol, 1979; 36: 479.

${ }^{24}$ Nath I, Narayanan RB, Mehra NK, Sharma AK, Gupte MD. Suppressor cells in human leprosy. Int J Lepr, 1979; (Suppl) 47: 391.

${ }^{25}$ Ramshaw IA, Bretchner PA, Parish CR. Regulation of the immune response. I. Suppression of delayed-type hypersensitivity by $\mathrm{T}$ cells from mice expressing humoral immunity. Eur. $J$. Immunol, 1976; 6: 674.

26 Zilko PJ, Dawkins RL, Holmes K, Witt C. Genetic control of suppressor lymphocyte function in myastenia gravis: Relationship of impaired suppressor function to HLA-B8/DRw3 and cold-reactive lymphocytotoxic antibodies. Clin Immunol Immunopathol, 1979; 14: 222.

${ }^{27}$ DeVries RRP, van Eden W, van Rood JJ. HLA-linked control of the course of $M$. leprae infections. Lepr Rev, 1981; (Suppl. 1) 52: 109.

${ }^{28}$ Kreisler JM, Arnaiz A, Perez B, Bootello A. Lymphotoxins in leprosy. Int J Lepr, 1975; 43: 91.

${ }^{29}$ Closs O, Reitan LJ, Negassi K, Harboe M, Belehu A. In vitro stimulation of lymphocytes in leprosy patients, healthy contacts of leprosy patients and subjects not exposed to leprosy. 
Comparison of an antigen fraction prepared from Mycobacterium leprae and tuberculin-purified protein derivative. Scand J Immunol, 1982; 16: 103.

${ }^{30}$ Convit J, Aranzazu N, Pinardi M, Ulrich M. Immunological changes observed in indeterminate and lepromatous leprosy patients and Mitsuda-negative contacts af ter the inoculation of a mixture of Mycobacterium leprae and BCG. Clin exp Immunol 1979; 36: 214.

31 Wemambu SNC, Turk JL, Waters MFR, Rees RJW. Erythema nodosum leprosum. A clinical manifestation of the Arthus phenomenon. Lancet, 1969; 2: 933.

32 Bjorvatn B, Barnetson R St C, Kronvall G, Zubler RH, Lambert PH. Immune complexes and complement hypercatabolism in patients with leprosy. Clin exp Immunol, 1976; 26: 388.

${ }^{33}$ Cöloğlu AS. Immune complex glomerulonephritis in leprosy. Lepr Rev, 1979; 50: 213.

34 Johny KV, Karat ABA, Rao PSS, Date A. Glomerulonephritis in leprosy. A percutaneous renal biopsy study. Lepr Rev, 1975; 46: 29.

35 Rea TH, Ridley DS. Lucio's phenomenon: A comparative histological study. Int J Lepr, 1979; 47: 161 . 